Running title: Bacteria in First Nation drinking water

\title{
Bacteria in drinking water sources of a First Nation reserve in Canada
}

Annemieke Farenhorst ${ }^{1 \ddagger}, \mathrm{Ru} \mathrm{Li}^{1 *}$, Musarrat Jahan ${ }^{1}$, Hein Min Tun ${ }^{2}$, Ruidong $\mathrm{Mi}^{1}$, Inoka Amarakoon $^{1}$, Ayush Kumar ${ }^{3,4}$, Ehsan Khafipour ${ }^{2,4} \ddagger$

${ }^{1}$ Department of Soil Science, University of Manitoba, Winnipeg, MB, Canada, R3T 2N2

${ }^{2}$ Department of Animal Science, University of Manitoba, Winnipeg, MB, Canada, R3T 2N2

${ }^{3}$ Department of Microbiology, University of Manitoba, MB, Canada, R3T 2N2

${ }^{4}$ Department of Medical Microbiology, University of Manitoba, Winnipeg, MB, Canada, R3T $2 \mathrm{~N} 2$

${ }^{*}$ Current address: Department of plant protection, Yunnan Agricultural University, Kunming, Yunnan province, China, 650201.

Co-corresponding authors:

Ehsan Khafipour: 225 Animal Science Bldg, 12 Dafoe Rd, Winnipeg, MB, Canada R3T 2N2;

Tel: 204-474-6112; Fax: 204-474-7628; E-mail: Ehsan.Khafipour@umanitoba.ca

Annemieke Farenhorst: 380 Ellis Bldg, 13 Freedman Crescent, Winnipeg, MB, Canada, R3T

2N2; Tel: 204-474-6858; Fax: 204-474-7642; Email: Annemieke.Farenhorst@umanitoba.ca 


\section{ABSTRACT}

Approximately $20 \%$ of the 600 First Nations reserves across Canada are under a drinking water advisory, often due to unacceptable levels of bacteria. In this study, we detected fecal bacteria at an alarmingly high frequency in drinking water sources in a fly-in First Nations community, most notably in buckets/drums of homes without running water where Escherichia coli levels ranged from 20 to $62,000 \mathrm{CFU} / 100 \mathrm{~mL}$. The water leaving the water treatment plant was free of E. coli and its free residual chlorine concentration $(0.67 \mathrm{mg} / \mathrm{L})$ was within the range typically observed for treated water in Canada. Water samples from taps in homes served by cisterns, and those sampled from the water truck and community standpipe, always showed unacceptable levels of $E$. coli ( 1 to 2,100 CFU/100mL) and free residual chlorine concentrations below the 0.2 $\mathrm{mg} / \mathrm{L}$ required to prevent bacterial regrowth. Samples from taps in homes served by piped water had lower levels of E. coli (0 to $2 \mathrm{CFU} / 100 \mathrm{~mL})$. DNA- and RNA-based 16S rRNA Illumina sequencing demonstrated that piped and cisterns water distribution systems showed an abundance of viable cells of Alphaproteobacteria indicative of biofilm formation in pipes and cisterns. The alpha diversity, based on observed OTUs and three other indices, was lowest in water truck samples that supplied water to the cistern and the low free residual chlorine concentration $(0.07 \mathrm{mg} / \mathrm{L})$ and predominance of Betaproteobacteria $(63 \%$ of viable cells $)$ that were immediately detected after the truck had filled up at the water treatment plant was indicative of contamination by particulate matter. Given these findings, First Nation residents living without running water and relying on inadequate water distribution systems are at higher risk of contracting water-born illnesses. We urge all governments in Canada to expand their investments in supporting and sustaining water as a human right in Canada's First Nations communities. 
GRAPHICAL ABSTRACT

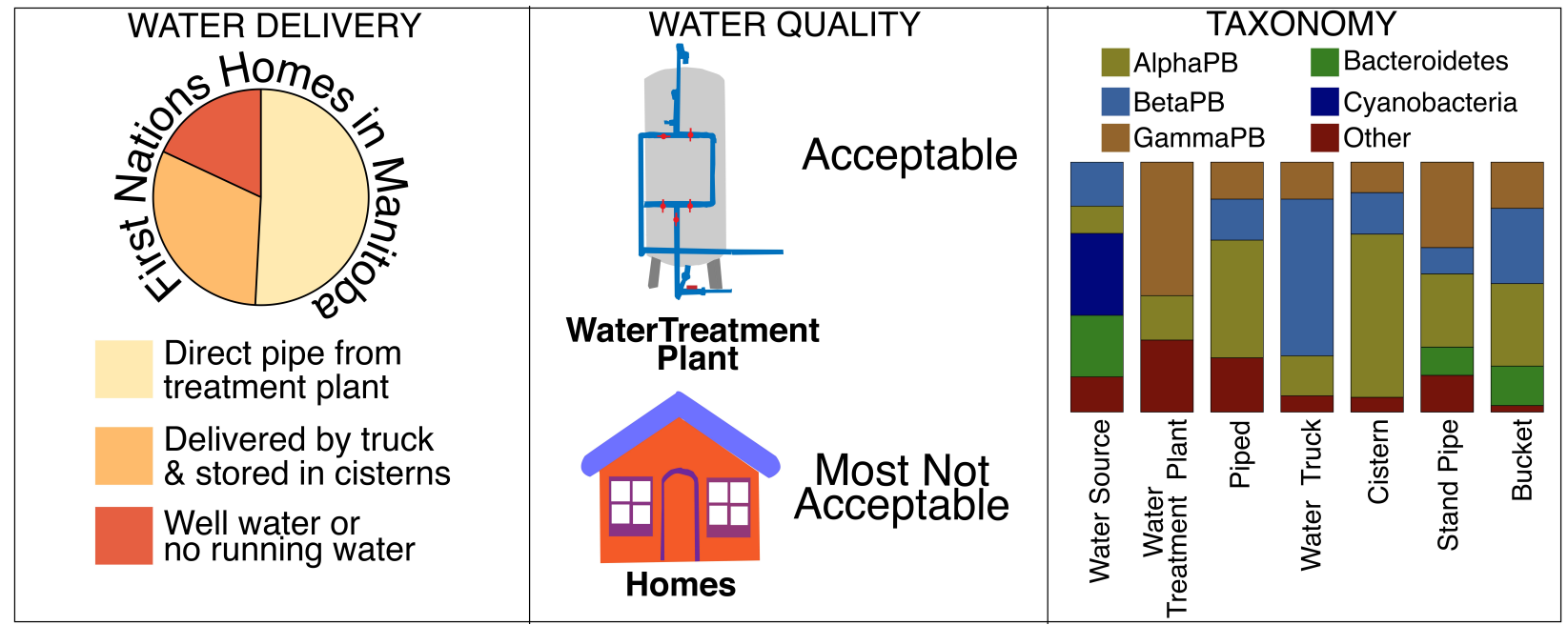

Keywords: Escherichia coli, 16S rRNA Illumina sequencing, Proteobacteria, piped water, cisterns, homes without running water.

\section{Introduction}

Most Canadians living in urban areas enjoy safe and plentiful drinking water which is largely the result of reliable water supplies due to advanced water treatment technologies, sufficient water operator knowledge and access to land management decision-making (Patrick, 2011).

Households in First Nations reserves in Canada do not have access to safe drinking water at the same rate, and poor drinking water supplies in many First Nations reserves likely contributes to increased risks for communicable diseases, decreased options for economic development and lost opportunities for food security and spiritual and cultural well-being (SSC-SAST 2010; Busby, 2016). In the spring 2016, out of the approximately 600 First Nations reserves in Canada, there are 158 Drinking Water Advisories (DWAs) in effect on 111 First Nations reserves (FNHA, 2016, Health Canada, 2016). Violations in bacterial counts has been cited as an important reason 
(43\%) for the poor drinking water quality in First Nations reserves, with no improvements to reducing the frequency of DWAs for decades (Health Canada, 2009a).

Chlorine is added during the drinking water treatment process to ensure the absence of pathogenic bacteria in potable water (Davies and Mazumder, 2003) and it has been long recognized that failure to do so contributes to increased risk for community waterborne disease outbreaks (Gorman and Wolman, 1939). Most bacteria are sensitive to chlorine and maintaining a free residual chlorine concentration greater than $0.2 \mathrm{mg} / \mathrm{L}$ throughout the water distribution system is important to prevent pathogenic bacteria regrowth (LeChevallier et al., 1996). However, bacteria are always present to a certain extent in drinking water distribution systems, where bacterial species are associated with the bulk water, biofilms, suspended solids and particulate matter in the system (Liu et al., 2016). Autochthonous bacteria may promote the growth of potentially pathogenic bacteria in water distribution systems (Berry et al., 2006; Eichler et al., 2006) and hence knowledge of microbial diversity in drinking water systems can be important, also because it helps to identify water distribution system discrepancies and disruptions (McCoy and VanBriesen, 2012).

Like most countries, the safety of the Canadian water supply is tested using culture-based techniques such as the determination of total coliforms and Escherichia coli in treated water. Although these techniques provide for important screening tools for recent fecal contamination, the majority of microorganisms present in the environment are not culturable and methods such as high throughput sequencing are required to characterize unculturable bacteria in water supplies (Eichler et al., 2006; Revetta et al., 2010; Lin et al., 2014; Gomez-Alvarez et al., 2016). 
Several studies have used high-throughput sequencing technologies to investigate bacterial community diversity in water distribution systems locations or components (Kwon, 2011; Pinto et al., 2012; Douterelo et al., 2013; Navarro-Noya et al., 2013). In a recent study, we highlight the importance for such investigations in First Nations communities in Canada (Fernando et al., 2016).

The objective of this study was to quantify bacteria in drinking water sources of selected homes in a fly-in First Nations community in the Island Lake Region of the province of Manitoba, Canada. Our study results indicate bacterial communities changes during water distribution, and further highlights the alarming frequency at which E. coli are present in First Nations drinking water supplies, particularly in homes with cisterns and no running water at all.

\section{Materials and Methods}

\subsection{Community and water distribution profile}

The water distribution system of a First Nation community in the Island Lake Region of Manitoba, Canada was examined. The community, which is accessible by plane year around and by ice roads in the winter, has an on reserve population of approximately 4,000 and a total registered population of about 4,500 , with a median age of about 20 years. The community has a water treatment plant (WTP) that is connected to approximately 300 homes that are receiving piped tap water. Approximately 150 homes rely on cisterns (water holding tanks) and receive their water from a water truck that fills up at the WTP. During the time of water collection for this study, there was one operational water truck in the community that was filling up cisterns 
non-stop. The remaining homes do not have running water and families use small plastic buckets to obtain their household water from the community standpipe or the lake and store the water in these buckets in their home, or have larger plastic drums outside the home that are filled up by the water truck. Ten homes without running water were included in this study of which six homes had buckets and in each case these buckets contained water that was obtained from the community standpipe. The community standpipe is in constant use and it is common to have a line-up of community members wanting to fill buckets. All water-filled buckets were in the home without lid but four buckets were lined inside with a garbage bag that served as a cover. One home had obtained water from the community standpipe using a larger closed container with a tap and this was stored outside. Three homes had larger drums that are stored outside with a lid and are filled by the water truck.

Water samples ( $\mathrm{n}=56)$ were collected between July 21-24, 2014 from the lake near the source intake of the WTP $(n=6)$, the WTP tap $(n=6)$, taps from homes served by piped water $(n=10)$, the hose of the water truck $(n=6)$, taps from homes with cisterns $(n=10)$, the community standpipe $(\mathrm{n}=8)$, and the buckets/drums in homes without running water $(\mathrm{n}=10)$. Sampling followed standard methods (SM; Rice et al., 2012) for sample bottle pre-treatment (SM 9060A) and preservation and storage (SM 9060B). During water collection, the Hatch Chlorine Pocket Colorimeter II (VWR, Mississauga, ON, Canada) was used to determine free residual and total residual chlorine following the adapted USEPA DPD Method 8021(Hach, 2002). For all other analysis, samples were transported in coolers to Winnipeg by air and processed within $24 \mathrm{~h}$ of collection for bacterial analyses. 


\subsection{Total coliform and E. coli counts}

Total coliform $(\mathrm{CFU} / 100 \mathrm{~mL})$ and $E$. coli $(\mathrm{CFU} / 100 \mathrm{~mL})$ were determined using the standard membrane filter procedure as outlined in SM 9222 (Rice et al., 2012), where CFU is the number of colony-forming units. Briefly, water samples (undiluted and diluted) were filtered through sterile $0.45 \mu \mathrm{m}$ polyethersulfone membranes (Mo Bio Laboratories, Carlsbad, CA, USA) and membranes were placed on Brilliant E. coli and coliform medium (Fisher Scientific, Ottawa, ON, Canada). Following incubation at $35^{\circ} \mathrm{C}$ for $24 \mathrm{~h}$, the numbers of purple and pink colonies were counted to quantify total coliform, with purple colonies being E. coli.

\subsection{S rRNA Illumina sequencing}

Sequencing of the 16S rRNA was carried out using DNA and RNA-based methods to differentiate dead from live cells (dormant cells as well as growing or non-growing metabolically active cells). Water $(500 \mathrm{~mL})$ was filtered through sterile polyethersulfone membranes $(0.22 \mu \mathrm{m}$ pore size; 47nm diameter; Mo Bio Laboratories, Carlsbad, CA, USA). DNA and RNA were extracted using Powerwater DNA and RNA isolation kits (Mo BIO Laboratories Inc, West Carlsbad, CA, USA), respectively, that included a bead-beating step for mechanical lysis of bacteria. DNaseI treatment step was included during RNA extraction to remove genomic DNA. cDNA synthesis was carried out using a reverse transcription kit (QuantiTec, Qiagen Scientific, Germantown, MD, USA).Quantification of DNA, RNA, and cDNA was carried out using NanoDrop 2000 spectrophotometer (Thermo Scientific, Waltham, MA, USA). The quality was measured by PCR amplification of 16S rRNA, using forward primer 27F (AGAGTTTGATCMTGGCTCAG) and reverse primer 342R (CTGCTGCSYCCCGTAG), after DNA and cDNA were normalized to the concentration of $10 \mathrm{ng} / \mu \mathrm{L}$ (Khafipour et al., 2009). 
A library of V4 region of 16S rRNA was constructed using modified F515 and R806 primers (Caporaso et al., 2012) as described previously (Derakhshani et al., 2016). PCR reaction for each sample was performed in duplicate and contained $1.0 \mu \mathrm{L}$ of pre-normalized DNA, 1.0 $\mu \mathrm{L}$ of each forward and reverse primers $(10 \mu \mathrm{M}), 12 \mu \mathrm{L}$ HPLC grade water (Fisher Scientific, Ottawa, ON, Canada) and $10 \mu \mathrm{L} 5$ Prime Hot MasterMix ${ }^{\circledR}$ (5 Prime, Inc., Gaithersburg, MD, USA). Reactions consisted of an initial denaturing step at $94^{\circ} \mathrm{C}$ for $3 \mathrm{~min}$, followed by 35 amplification cycles at $94^{\circ} \mathrm{C}$ for $45 \mathrm{sec}, 50^{\circ} \mathrm{C}$ for $60 \mathrm{sec}$, and $72^{\circ} \mathrm{C}$ for $90 \mathrm{sec}$; finalized by an extension step at $72^{\circ} \mathrm{C}$ for $10 \mathrm{~min}$ in an Eppendorf Mastercycler pro (Eppendorf, Hamburg, Germany) followed by the purification of the PCR products using the ZR 96 DNA Clean up Kit (ZYMO Research, Irvine, CA, USA). The V4 library was then generated by pooling $200 \mathrm{ng}$ of each sample, quantified by Picogreen dsDNA (Invitrogen, Burlington, NY, USA). The pooled library was diluted to a final concentration of $5 \mathrm{pM}$ using pre-chilled hybridization buffer (HT1) (Illumina, Irvine, CA, USA) measured by Qubit 2.0 Fluorometer (Life technologies, Ottawa, ON, Canada). In the final step, $15 \%$ of PhiX control library was spiked into the amplicon library to improve the unbalanced and biased base composition. For Illumina sequencing, customized sequencing primers for read1 (5'-TATGGTAATTGTGTGCCAGCMGCCGCGGTAA-3'), read2 (5' AGTCAGTCAGCCGGACTACHVGGGTWTCTAAT-3') and index read (5'ATTAGAWACCCBDGTAGTCCGGCTGACTGACT-3'), and mixture of sample and PhiX library were added to the MiSeq Reagent Kit V2 (300-cycle; Illumina, San Diego, CA, USA). The 150 paired-end sequencing reaction was performed on a MiSeq platform (Illumina, San Diego, CA, USA) at the Gut Microbiome Laboratory. The sequence data are uploaded into the 
Sequence Read Archive (SRA) or NCBI (http://www.ncbi.nlm.nih.gov/sra) and accessible through accession number SRR2983316.

\subsection{Bioinformatics}

The FLASH assembler (Magoč and Salzberg, 2011) was used to merge overlapping paired-end Illumina fastq files and all the sequences with mismatches or ambiguous calls in the overlapping region were discarded. The output of fastq file was then analyzed by downstream computational QIIME pipelines (Caporaso et al., 2010). Assembled reads were de-multiplexed according to barcode sequences and exposed to additional quality-filters so that reads with ambiguous calls and those with phred quality scores (Q-scores) below 20 were discarded. Chimeric reads were filtered using UCHIME (Edgar et al., 2011) and sequences were assigned to Operational Taxonomic Units (OTU) using the QIIME implementation of UCLUST (Edgar, 2010) at 97\% pair wise identity threshold. Taxonomies were classified to the representative sequence of each OTU using RDP classifier (Wang et al., 2007) and aligned with the Greengenes Core reference database (DeSantis et al., 2006) using PyNAST algorithms (Caporaso et al., 2010). A phylogenetic tree was built with FastTree 2.1.3. (Price et al., 2010) for classifying microbial taxa.

\subsection{Statistical analysis}

Total coliforms and E. coli data followed a negative binominal distribution and were subjected to Analysis of Variance (ANOVA) using PROC GLIMMIX in SAS 9.4. (SAS Institute Inc., 2013) to compare differences in total coliforms or E. coli counts between water sources. The Tukey multiple comparison procedure was used for all pairwise comparison of treatment means, with treatments being considered significantly different at $P<0.05$. For each water source, total 
sequence counts between DNA- versus RNA-based methods were compared using the paired ttest in SAS to determine the impact of water treatment on bacteria viability within the distribution systems. The OTUs for observed species number, Chaol estimator of species richness and Shannon and Simpson diversity indices were calculated in QIIME to evaluate alpha-diversity within samples and displaying differences between water sources using box plots developed in OriginPro 2016 (OriginLab, Northampton, MA).

\section{Results and Discussion}

The total $(0.94 \mathrm{mg} / \mathrm{L})$ and free $(0.67 \mathrm{mg} / \mathrm{L})$ residual chlorine in the water leaving the WTP was within the range of free residual chlorine concentration $(0.4$ to $2.0 \mathrm{mg} / \mathrm{L})$ typically observed for water treatment plants in Canada (Health Canada 2009b). No coliforms or E. coli were detected in the samples from the WTP tap, indicating that the water treatment process effectively removed these viable, culturable coliforms that were present in the source (lake) water (Fig 1).

All other samples always showed free residual chlorine concentrations below the $0.2 \mathrm{mg} / \mathrm{L}$ required to prevent bacterial regrowth (LeChevallier et al., 1996). This included piped (0.05 $\mathrm{mg} / \mathrm{L} \pm 71 \%$, mean \pm coefficient of variation $)$ and cistern $(0.05 \mathrm{mg} / \mathrm{L} \pm 84 \%)$ homes, the buckets/drums in homes without running water $(0.07 \mathrm{mg} / \mathrm{L} \pm 86 \%)$, the water truck $(0.07 \mathrm{mg} / \mathrm{L})$, and the community standpipe $(0.07 \mathrm{mg} / \mathrm{L})$. These low concentrations would be atypical for most off-reserve locations because, based on 3,590 drinking water systems across nine provinces and territories in Canada, the levels of free residual chlorine in the distribution pipe lines typically range from 0.4 to $1.2 \mathrm{mg} / \mathrm{L}$ at intermediate points, and from 0.04 to $0.8 \mathrm{mg} / \mathrm{L}$ at the end of the 
distribution line (Health Canada 2009b). However, we have detected such low free residual chlorine concentrations in the drinking water supplies of homes in other First Nations reserves in Canada (unpublished data).

Total coliforms significantly increased in the order of (piped homes $=$ water truck) $<$ (source water $=$ cistern homes $)<($ community pipe $=$ buckets $/$ drums of homes without running water $)$ (Fig 1). E. coli was significantly lower in piped homes $(1 \mathrm{CFU} / 100 \mathrm{~mL}, \pm 83 \%)$ and water truck $(6 \mathrm{CFU} / 100 \mathrm{~mL}, \pm 25 \%)$ than other drinking water sources. The cisterns $(65 \mathrm{CFU} / 100 \mathrm{~mL}, \pm$ $215 \%$ ) had statistically similar levels of E. coli as source (lake) water (97 CFU/100mL, $\pm 51 \%$ ). The community standpipe $(1,260 \mathrm{CFU} / 100 \mathrm{~mL}, \pm 73 \%)$ and buckets/drums homes without running water $(7,780 \mathrm{CFU} / 100 \mathrm{~mL}, \pm 260 \%)$ showed alarmingly high levels of $E$. coli which was in case of the buckets/drums significantly greater than the levels observed in source (lake) water. The potential health risks associated with human exposure to $E$. coli in treated drinking water has long been documented (Swerdlow et al., 1992).

The average sequence count for viable+nonviable cells (DNA-based method) ranged from a minimum of 24,676 in the standpipe samples to a maximum of 37,111 in the piped samples (Fig 2). The average sequence counts for viable cell (RNA-based method) ranged from a minimum of 6,180 in the WTP samples to a maximum of 27,551 in the source (lake) water samples. In case of the WTP, piped water and community standpipe (which is also piped water), the average sequence counts were significantly smaller in the RNA- than DNA-based method (Fig 2), indicating that water treatment reduces the number of viable cells. The average sequence counts were statistically similar for the RNA- and DNA-based methods in all other cases, particularly 
showing that most of the bacteria in the buckets/drums of homes without running water were viable cells (Fig 2). The average sequence counts of viable cells in the buckets/drums of homes without running water $(26,590)$ were relatively similar to that detected in source (lake) water $(27,551)$

Across all water samples, a total of 47 and 36 bacterial phyla were detected in the DNA- and RNA-based methods, respectively (Fig 3). The number of phyla numerically decreased in the order of piped $[36,28]>$ cistern $[33,24]>$ community standpipe $[29,23]>$ buckets/drums $[28$, $18]>$ source $($ lake) water $[26,22]>$ WTP $[18,11]>$ water truck $[12,9]$ samples, with numbers referring to phyla classified based on DNA- and RNA-based methods, respectively.

Source (lake) water had a relatively high alpha-diversity based on all indices (Fig 4) and most of the bacteria cells were viable because the average sequence counts were statistically similar for the RNA-and DNA-based methods (Fig 2). Viable cells were particularly associated with Cyanobacteria (32.8\%), Bacteroidetes (24.6\%), Betaproteobacteria (17.6\%) and Alphaproteobacteria (10.9\%) (Fig 3). Actinobacteria were abundantly found using the DNAbased method but not with the RNA-based method. Cyanobacteria are an indication of increased nutrient concentrations in freshwater lakes and can produce toxins harmful to mammals (Hudon et al., 2014). Bacteroidetes, Betaproteobacteria, and Actinobacteria have been shown to be abundant in other freshwater lakes (Boucher et al., 2006; Tang et al., 2015).

Proteobacteria were the predominant phyla in the treated water, particularly Alpha-, Beta-, and Gammaproteobacteria (Fig 3). Alpha-, Beta-, and Gammaproteobacteria are usually the most 
prevalent fraction of bacteria in treated drinking water sources, regardless of the type of water distribution system or treatment, and sampling time (Kalmbach et al., 1997; Tokajianet al., 2005; McCoy and VanBriese, 2012). The most commonly detected viable cells in the treated water were bacteria belonging to the orders of Caulobacterales, Rhizobiales, Rhodospirillales, Sphingomonadales, Burkholderiales, Pseudomonadales and Xanthomonadales (Table 1).

The average sequence count for viable cells numerically increased between the WTP samples $(6,180)$ and the piped $(14,472)$, community fountain $(12,210)$, water truck $(14,505)$, and cistern samples $(23,218)$, indicating the regrowth or introduction of bacteria during water distribution to the homes. The viable cells in the water leaving the WTP were dominated by Gammapoteobacteria (Fig 3), particularly members of Xanthomonadales order (Table 1), while the enrichment of viable Alphaproteobacteria in homes with piped and cistern water (Fig 3) indicates that biofilms are present on the inner surfaces of pipes and cisterns in the water distribution system of this community (Mathieu et al., 2009; Henne et al., 2012; Liu et al., 2014). Biofilms attached on the internal surface of pipes are a major reservoir of increasing bacterial levels in disinfected water during distribution through pipes (Berry et al., 2006; Revetta et al., 2013; Wu et al., 2015). Rhizobiales, Rhodospirillales and Sphingomonadales are bacterial orders commonly detected in biofilms (Liu et al., 2012; Shaw et al., 2015; Rozej et al., 2015) and the viable sequence counts of these bacterial orders substantially increased during the distribution of treated water from the WTP to homes with piped water or cisterns, and the community fountain (Table 1). 
We sampled the water truck immediately after it had filled up at the WTP and the sudden decrease in free residual chlorine concentration from $0.67 \mathrm{mg} / \mathrm{L}$ (WTP) to $0.07 \mathrm{mg} / \mathrm{L}$ (truck) (Fig 1) is an indication that the truck was contaminated with dissolved and/or free particulate matter reacting with chlorine. The water truck samples had a relatively low alpha-diversity based on all indices (Fig 4) with a distinct abundance of viable cells of Betaproteobacteria $(62.7 \%)$ that were also present as viable cells in buckets /drums of homes without running water (30.1\%) (Fig 3). The viable Betaproteobacteria in the water truck were almost exclusively of the order Burkholderiales $(>96 \%)$, which were also the predominant viable order in the buckets/drums of homes without running water (36\%) (Table 1). Burkholderiales are common in soil (Lauber et al., 2009), as well as in atmospheric dust (Itani et al., 2016), and hence their viable abundance in water truck and bucket/drums samples (Table 1) indicates recent contamination of soil (dust) particles. Such contamination can occur because of the dust particles in the air entering the truck when it is filled up at the WTP (which occurs many times per day) and because the buckets in homes without running water do not have a lid while often being positioned on the floor in homes sometimes near the outdoor entrance. Relative to the treated water leaving the WTP, viable cells of Burkholderiales were more abundant in water from homes with cistern and pipes, as well as the community standpipe, suggesting that Burkholderiales may also enter the water distribution systems in this community as a result of contaminated groundwater flowing into cracked underground cisterns and pipes.

Substantial numbers of viable cells of Bacteroidetes were present in samples from the source (lake) water (24.6\%) and homes with buckets/drums (15.8\%) (Fig 3). Bacteroidetes are abundant members of gastrointestinal tract of human and warm-blooded animals, and thus can be 
introduced via feces and saliva (Allsop and Stickler, 1985; Keijser et al., 2008; Marchesi, 2010). The majority of members in this phyla are obligate anaerobes and are unlikely to survive long outside the intestinal tract or host body, and are hence a sign of recent contamination (Dick and Field, 2004). The presence of viable Bacteroidetes (15.8\%) in buckets/drums (Fig 3 ) is also an indication of soil (dust) contamination as Bacteroidetes originating from leaf surfaces, soil and animal fecal matter sources are present in near-surface atmospheric particulate matter (Bowers et al., 2011).

Waterborne disease outbreaks leading to mortalities were relatively common in Canada in the beginning of the $20^{\text {th }}$ century (Gormanand Wolman, 1939), but such outbreaks are now relatively rare (Woo et al., 2003; Butler-Jones, 2013). Despite, waterborne intestinal infectious diseases may account for up to one-fifth of the reported communicable disease cases in Canada (Teschke et al., 2010), with a greater portion of reported cased being associated with pre-teens and the elderly (Schuster et al., 2005). The actual number of individuals affected by waterborne intestinal infectious diseases may be substantially greater than that reported, by many folds, because suffers may not be seeking professional medical attention for reasons that could include the mildness of the symptoms, the short duration of symptoms, or attempts to self-medicate (Schuster et al., 2005; Sockett and Poulin, 2011). The majority of reported waterborne disease events occur in small and medium-sized communities such as First Nations reserves and enhancing water treatment effectiveness in these communities is key to reducing waterborne intestinal infectious diseases in Canada (Sockett and Poulin, 2011). 
Most of 45,000+ drinking water systems in Canada are small systems that provide treated drinking water to communities with less than 5,000 individuals (Butler-Jones, 2013). Our overall findings indicate that the effectiveness of drinking water distribution in this Island Lake community is far below the standard what would be expected of a developed country like Canada, even for small communities. The direct impact of the poor water quality in this community on human health is difficult to access given that an increased immunity to waterborne pathogens may occur over time (Teschke et al., 2010). However, we are concerned that the poor drinking water quality in homes with cisterns and no running water could potentially pose a serious threat to individual human and community health. We urged all governments in Canada to support access to clean drinking water as a human right in this and other First Nations communities in Canada. Improvements in this community can range from implementing initiatives to provide families in homes without running water with more secure drinking storage water containers than open buckets in homes, ensuring additional water trucks, cleaning contaminated cisterns, and fixing leaking pipes. Most importantly, investments to connect homes directly to the water treatment plant via improved pipe lines is key to reducing human exposure to water-borne illnesses while enhancing options for families to participate in economic development, food security and spiritual and cultural well-being in their community.

\section{Conclusion}

This study detected concerning levels of total coliforms and E. coli in the drinking water supplies of homes on a fly-in community in the Island Lake region of Manitoba, Canada, particularly in homes without running water. Proteobacteria was the most common phylum detected throughout 
the drinking water distribution systems and supplies. Viable cells of Gammaproteobacteria were most prevalent bacteria in the water leaving the WTP, but the bacterial composition changed during water distribution with the water truck and buckets/drums being dominated by Betaproteobacteria because of soil (dust) contamination while homes with piped or cisterns were dominated by Alphaproteobaceria because of biofilm formation. The residual free chlorine levels in the pipes, water truck and cisterns are too low to prevent bacterial regrowth and/or disinfect bacteria potentially enter the system as a result of (soil) dust contamination and inflow of contaminated groundwater into cracks of the pipes and cisterns. The drinking water quality in this community is poor and, relative to urban populations, First Nations families living on reserves may be at increased risks of contracting water-born illnesses.

Acknowledgements: Funding for this research was provided by the Natural Sciences and Engineering Research Council of Canada through its Collaborative Research and Training Experience Program (grant\# 432009-2013). We also gratefully thank the First Nation community for on-going collaborations.

\section{References}

Allsop, K., Stickler, D.J., 1985. An assessment of Bacteroides fragilis group organisms as indicators of human faecal pollution. J. Appl. Bacteriol. 58, 95-99.

Berry, D., Xi, C.W., Raskin, L., 2006. Microbial ecology of drinking water distribution systems. Curr. Opin. Biofechnol. 17, 297-302. 
Boucher, D., Jardillier, L., Debroas, D., 2006. Succession of bacterial community composition over two consecutive years in two aquatic systems: A natural lake and a lake-reservoir. FEMS Microbiol. Ecol. 55, 79-97.

Bowers, R.M., Sullivan, A.P., Costello, E.K., Collett, J.L., Knight, R., Fierer, N., 2011. Sources of bacteria in outdoor air across cities in the mid-western United States. Appl. Environ. Microbiol. 77, 6350-6356.

Busby, K., 2016. Providing essential services of reasonable quality to all Canadians: Understanding section 36(1)(c) of the constitution act, 1982. Review of Constitutional Studies/ Revue D'etudes Constitutionnelles, 20, 2, 191-212.

Butler-Jones, D., 2013. The Chief Public Health Officer's Report on the state of public health in Canada, 2013: Infectious Disease - The Never-ending Threat. Public Health Agency of Canada, 2013.

Caporaso, J.G., Kuczynski, J., Stombaugh, J., Bittinger, K., Bushman, F.D., Costello, E.K., 2010. QIIME allows analysis of high-throughput community sequencing data. Nat. Methods 7, 335-6.

Caporaso, J.G., Lauber, C.L., Walters, W.A., Berg-Lyons, D., Huntley, J., Fierer, N., Owens, S.M., Betley, J., Fraser, L., Bauer, M., Gormley, N., Gilber, J.A., Smith, G., Knight, R., 2012. 
Ultra-high-throughput microbial community analysis on the Illumina HiSeq and MiSeq platforms. ISME J. 6, 1621-4.

Davies, J.M., Mazumder, A., 2003. Health and environmental policy issues in Canada: The role of watershed management in sustaining clean drinking water quality at surface sources. J. Environ. Manag. 68, 273-286.

Derakhshani, H., Tun, H.M., Khafipour, E., 2016. An extended single index multiplexed 16S rRNA sequencing for microbial community analysis on MiSeq Illumina platforms. J. Basic Microbiol. 56, 321-326.

DeSantis, T.Z., Hugenholtz, P., Larsen, N., Rojas, M., Brodie, E.L., Keller, K., Huber, T., Dalevi, D., Hu, P., Andersen, G.L., 2006. Greengenes, a chimera-checked 16S rRNA gene database and workbench compatible with ARB. Appl. Environ. Microbiol. 72, 5069-72.

Dick, L.K., Field, K.G., 2004. Rapid estimation of numbers of fecal Bacteroidetes by use of a quantitative PCR assay for 16S rRNA genes. Appl. Environ. Microbiol. 70, 5695-5697.

Douterelo, I., Sharpe, R. L., Boxall, J.B., 2013. Influence of hydraulic regimes on bacterial community structure and composition in an experimental drinking water distribution system. Water Res. 47, 503-516. 
Edgar, R.C., Haas, B.J., Clemente, J.C., Quince, C., Knight, R., 2011. UCHIME improves sensitivity and speed of chimera detection. Bioinformatics 27, 2194-2200.

Edgar, R.C., 2010. Search and clustering orders of magnitude faster than BLAST. Bioinformatics $26,2460-2461$.

Eichler, S., Christen, R., Höltje, C., Westphal, P., Bötel, J., Brettar, I., Mehling, A., Höfle, M.G., 2006. Composition and dynamics of bacterial communities of a drinking water supply system as assessed by RNA-and DNA-based 16S rRNA gene fingerprinting. Appl. Environ. Microbiol. 72, $1858-1872$.

Fernando, D.M., Tun, H.M., Poole, J., Patidar, R., Li, R., Mi, R., Amarawansha, G.E., Fernando, W.D., Khafipour, E., Farenhorst, A., Kumar, A., 2016. Detection of antibiotic resistance genes in source and drinking water samples from a First Nation community in Canada. Appl. Environ. Microbiol. AEM-00798.

FNHA, 2016. Drinking Water Safety Program, First Nations Health Authority http://www.fnha.ca/what-we-do/environmental-health/drinking-water-safety-program (last accessed May 19, 2016).

Gomez-Alvarez, V., Pfaller, S., Pressman, J.G., Wahman, D.G., Revetta, R.P., 2016. Resilience of microbial communities in a simulated drinking water distribution system subjected to 
disturbances: Role of conditionally rare taxa and potential implications for antibiotic-resistant bacteria. Environ. Sci. Water Res. Technol. DOI: 10.1039/C6EW00053C.

Gorman, A.E., Wolman, A., 1939. Water-borne outbreaks in the United States and Canada, and their significance. J. Am. Water Works Assoc. 31, 225-373.

Hach, C., 2002. Water analysis handbook, Loveland, Colorado.

Health Canada, (2009a). Drinking water advisories in First Nations communities in Canada. A National Overview 1995-2007. Health Canada, Ottawa, Ontario. (Catalogue No. H34208/2009E-PDF).

Health Canada, (2009b). Guidelines for Canadian Drinking Water Quality: Guideline Technical Document - Chlorine. Water, Air and Climate Change Bureau, Healthy Environments and Consumer Safety Branch, Health Canada, Ottawa, Ontario. (Catalogue No. H128-1/09-588E).

Health Canada, (2016). Drinking Water Advisories in First Nations Communities, Health Canada, Ottawa, Ontario. http://www.hc-sc.gc.ca/fniah-spnia/promotion/public-publique/waterdwa-eau-aqep-eng.php\#more. (last accessed May 19, 2016).

Henne, K., Kahlisch, L., Brettar, I., Höfle, M., 2012. Analysis of structure and composition of bacterial core communities in mature drinking water biofilms and bulk water of a city wide network in Germany. Appl. Environ. Microbiol. 78,(10): 3530-3538. 
Hudon, C., De Sève, M., Cattaneo, A., 2014. Increasing occurrence of the benthic filamentous cyanobacterium Lyngbya wollei: A symptom of freshwater ecosystem degradation. Freshwater Sci. 33, 606-618.

Itani, G.N., Smith, C.A., 2016. Dust rains deliver diverse assemblages of microorganisms to the Eastern Mediterranean. Sci. Rep. 6, 22657.

Kalmbach, S., Manz, W., Szewzyk, U., 1997. Isolation of new bacterial species from drinking water biofilms and proof of their in situ dominance with highly specific 16S rRNA probes Appl. Environ. Microbiol. 63, 4164-4170.

Khafipour, E., Li, S., Plaizier, J.C., Krause, D.O., 2009. Rumen microbiome composition determined using two nutritional models of subacute ruminal acidosis. Appl. Environ. Microbiol. $75,7115-7124$.

Keijser, B.J., Zaura, E., Huse, S.M., Van Der Vossen, J.M., Schuren, F.H., Montijn, R.C., Ten Cate, J.M., Crielaard, W., 2008. Pyrosequencing analysis of the oral microflora of healthy adults. J. Dent. Res. 87, 1016-1020.

Kwon, S., Moon, E., Kim, T.S., Hong, S., Park, H.D., (2011). Pyrosequencing demonstrated complex microbial communities in a membrane filtration system for a drinking water treatment plant. Microbes Environ. 26, 149-155. 
Lauber, C.L., Hamady, M., Knight, R., Fierer, N., 2009. Pyrosequencing-based assessment of soil $\mathrm{pH}$ as a predictor of soil bacterial community structure at the continental scale. Appl. Environ. Microbiol. 75, 5111-5120.

LeChevallier, M.W., Welch, N.J., Smith, D.B., 1996. Full-scale studies of factors related to coliform regrowth in drinking water. Appl. Environ. Microbiol. 62, 2201-2211.

Lin, W., Yu, Z., Zhang, H., Thompson, I.P., 2014. Diversity and dynamics of microbial communities at each step of treatment plant for potable water generation. Water Res. 52, 218230.

Liu, G., Ling, F.Q., Van der Mark, E.J., Zhang, X.D., Knezev, A., Verberk, J.Q.J.C., Van der Meer, W.G.J., Medema, G.J., Liu, W.T., Van Dijk, J.C., 2016. Comparison of particle-associated bacteria from a drinking water treatment plant and distribution reservoirs with different water sources. Sci. Rep. 6, 20367.

Liu, R.Y., Yu, Z.S., Guo, H.G., Liu, M.M., Zhang, H.X., Yang, M., 2012. Pyrosequencing analysis of eukaryotic and bacterial communities in faucet biofilms. Sci. Total Environ. 435, $124-131$. 
Liu R.Y., Zhu, J.G., Yu. Z.S., Joshi, D., Zhang, H.X., Lin, W.F., Yang, M., 2014. Molecular analysis of long-term biofilm formation on PVC and cast iron surfaces in drinking water distribution system. J. Environ. Sci. 26, 865-874.

Magoč T., Salzberg S.L., 2011. FLASH: fast length adjustment of short reads to improve genome assemblies. Bioinformatics 27, 2957-63.

Marchesi, J.R., 2010. Prokaryotic and eukaryotic diversity of the human gut. Adv. Appl. Microbiol. 72, 43-62.

Mathieu, L., Bouteleux, C., Fass, S., Angel, E., Block, J.C., 2009. Reversible shift in the $\alpha-, \beta-$ and $\gamma$-proteobacteria populations of drinking water biofilms during discontinuous chlorination. Water Res. 43, 3375-3386.

McCoy, S.T., VanBriese, J.M., 2012. Temporal variability of bacterial diversity in a chlorinated drinking water distribution systems. J. Environ. Eng. 138, 786-795.

Navarro-Noya, Y.E., Suárez-Arriaga, M.C., Rojas-Valdes, A., Montoya-Ciriaco, N.M., GómezAcata, S., Fernández-Luqueño, F., Dendooven, L., 2013. Pyrosequencing analysis of the bacterial community in drinking water wells. Microb. Ecol. 66, 19-29.

Patrick, R.J., 2011. Uneven access to safe drinking water for First Nations in Canada: Connecting health and place through source water protection. Health Place 17, 386-389. 
Pinto, A.J, Xi, C., Raskin, L., 2012. Bacterial community structure in the drinking water microbiome is governed by filtration processes. Environ. Sci. Technol. 46, 8851-8859.

Price, M.N., Dehal, P.S., Arkin, A.P., 2010. FastTree 2-approximately maximum-likelihood trees for large alignments. PloS one 5, e9490.

Revetta, R. P., Pemberton, A., Lamendella, R., Iker, B., Santo Domingo, J.W., 2010. Identification of bacterial populations in drinking water using 16S rRNA-based sequence analyses. Water Res. 44, 1353-1360.

Rice, E.W., Baird, R.B., Eaton, A.D., Clesceri, L.S., 2012. Standard methods for the examination of water and waste waters, 22nd ed. American Public Health Association, American Water Works Association, Water Environment Federation, Washington, DC.

Rożej, A., Cydzik-Kwiatkowska, A., Kowalska, B., Kowalski, D., 2015. Structure and microbial diversity of biofilms on different pipe materials of a model drinking water distribution systems. World J. Microbiol. Biotechnol. 31, 37-47.

Shaw, J.L., Monis, P., Weyrich, L.S., Sawade, E., Drikas, M., Cooper, A.J., 2015. Using amplicon sequencing to characterize and monitor bacterial diversity in drinking water distribution systems. Appl. Environ. Microbiol. 81, 6463-6473. 
Schuster, C.J., Ellis, A.G., Robertson, W.J., Charron, D.F., Aramini, J.J., Marshall, B.J., Medeiros, D.T., 2005. Infectious disease outbreaks related to drinking water in Canada, 19742001. Can. J. Public Health, 96, 254-258.

Sockett, P., Poulin, D., 2011. Procedural Guidelines for Waterborne Disease Events in First Nations Communities South of $60^{\circ}$, Health Canada First Nations and Inuit Health Branch, Health Canada, Ottawa, Ontario. (Catalogue No. H34-228/2011E).

SSC-SAST 2010. Canada's Response to the 2009 H1N1 Influenza Pandemic. The Standing Senate Committee on Social Affairs, Science and Technology, Ottawa, Ontario. http://www.parl.gc.ca/Content/SEN/Committee/403/soci/rep/rep15dec10-e.pdf. (last accessed September 14, 2016).

Swerdlow, D.L., Woodruff, B.A., Brady, R.C., Griffin, P.M., Tippen, S., Donnell, H.D., Geldreich, E., Payne, B.J., Meyer, A., Wells, J.G., Greene, K.D., 1992. A waterborne outbreak in Missouri of Escherichia coli O157: H7 associated with bloody diarrhea and death. Ann. Intern. Med. 117, 812-819.

Tang, X., Xie, G., Shao, K., Dai, J., Chen, Y., Xu, Q., Gao, G., 2015. Bacterial community composition in Oligosaline Lake Bosten: Low overlap of Betaproteobacteria and Bacteroidetes with freshwater ecosystems. Microbes Environ. 30, 180.

Teschke, K., Bellack, N., Shen, H., Atwater, J., Chu, R., Koehoorn, M., MacNab, Y.C., Schreier, H., Isaac-Renton, J.L., 2010. Water and sewage systems, socio-demographics, and duration of 
residence associated with endemic intestinal infectious diseases: A cohort study. BMC Public Health 10, p.1.

Tokajian, S.T., Hashwa, F.A., Hancock, I.C., Zalloua, P.A., 2005. Phylogenetic assessment of heterotrophic bacteria from a water distribution system using 16S rDNA sequencing. Can. J. Microbiol. 51, 325-335.

Wang, Q., Garrity, G. M., Tiedje, J.M., Cole, J.R., 2007. Naive Bayesian classifier for rapid assignment of rRNA sequences into the new bacterial taxonomy. Appl. Environ. Microbiol.73, $5261-7$.

Woo, D.M., Vicente, K.J., 2003. Sociotechnical systems, risk management, and public health: Comparing the North Battleford and Walkerton outbreaks. Reliab. Eng. Syst. Safe. 80, 253-269.

Wu, H., Zhang, J., Mi, Z., Xie, S., Chen, C., Zhang, X., 2015. Biofilm bacterial communities in urban drinking water distribution systems transporting waters with different purification strategies. Applied Appl. Microbiol. Biotechnol. 99, 1947-1955. 


\section{FIGURES}

Figure 1: Total coliforms (CFU/100 mL) and E. coli (CFU/100 mL) detected in source (lake) water and the drinking water supplies in the First Nation community examined. Different capital letters indicate significant differences in total coliform levels. Different lower case letter indicate significant differences in E. coli levels. WTP (water treatment plant) samples had no detectable total coliforms and $E$. coli and these samples were excluded from the statistical analyses. $\mathrm{CP}=$ community standpipe. Bars are means with standard errors.

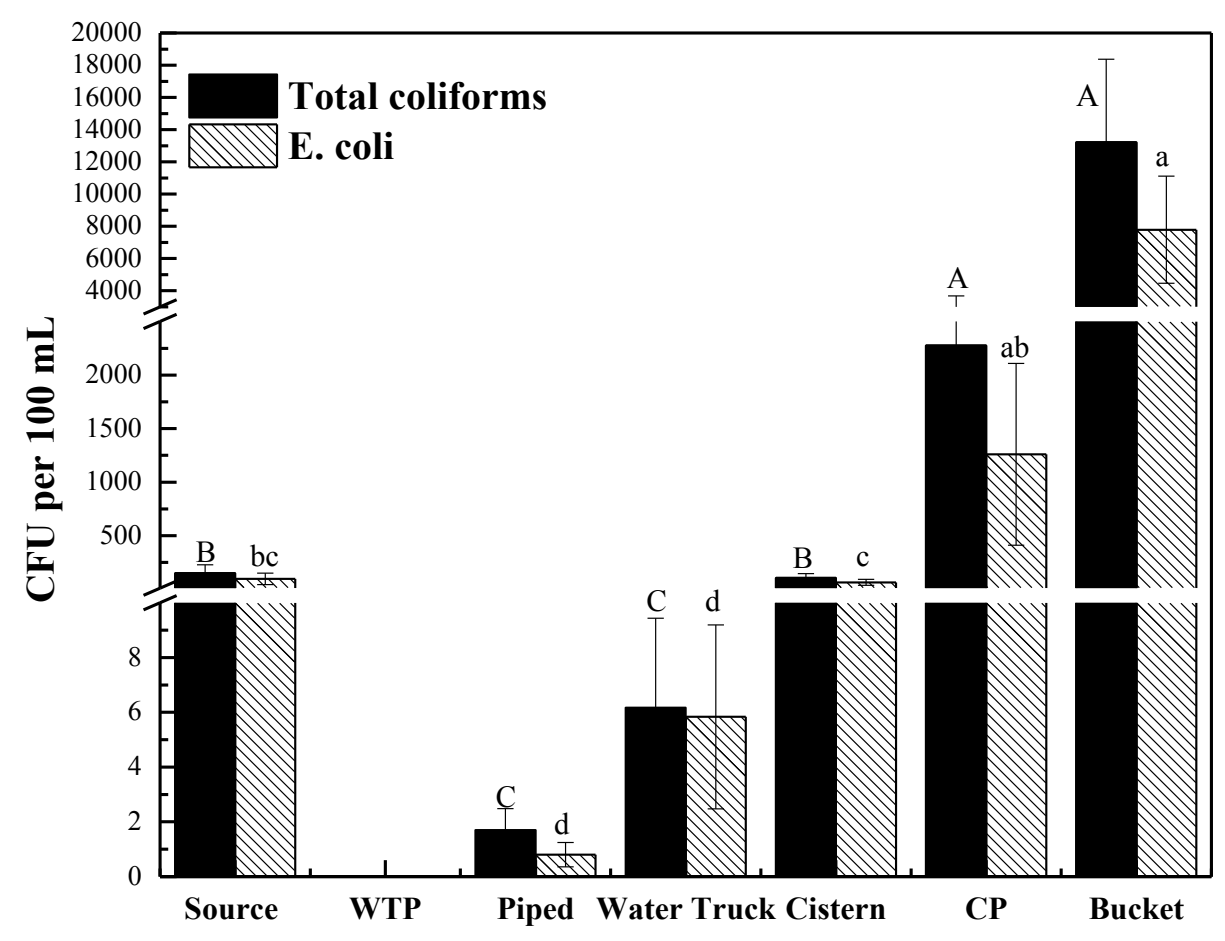


Figure 2: Mean sequence counts detected in source (lake) water and the drinking water supplies in the First Nation community examined. Different letters indicate significant differences in sequence counts obtained using DNA- versus RNA-based methods. WTP = water treatment plant. $\mathrm{CP}=$ community standpipe. Bars are means with standard errors.

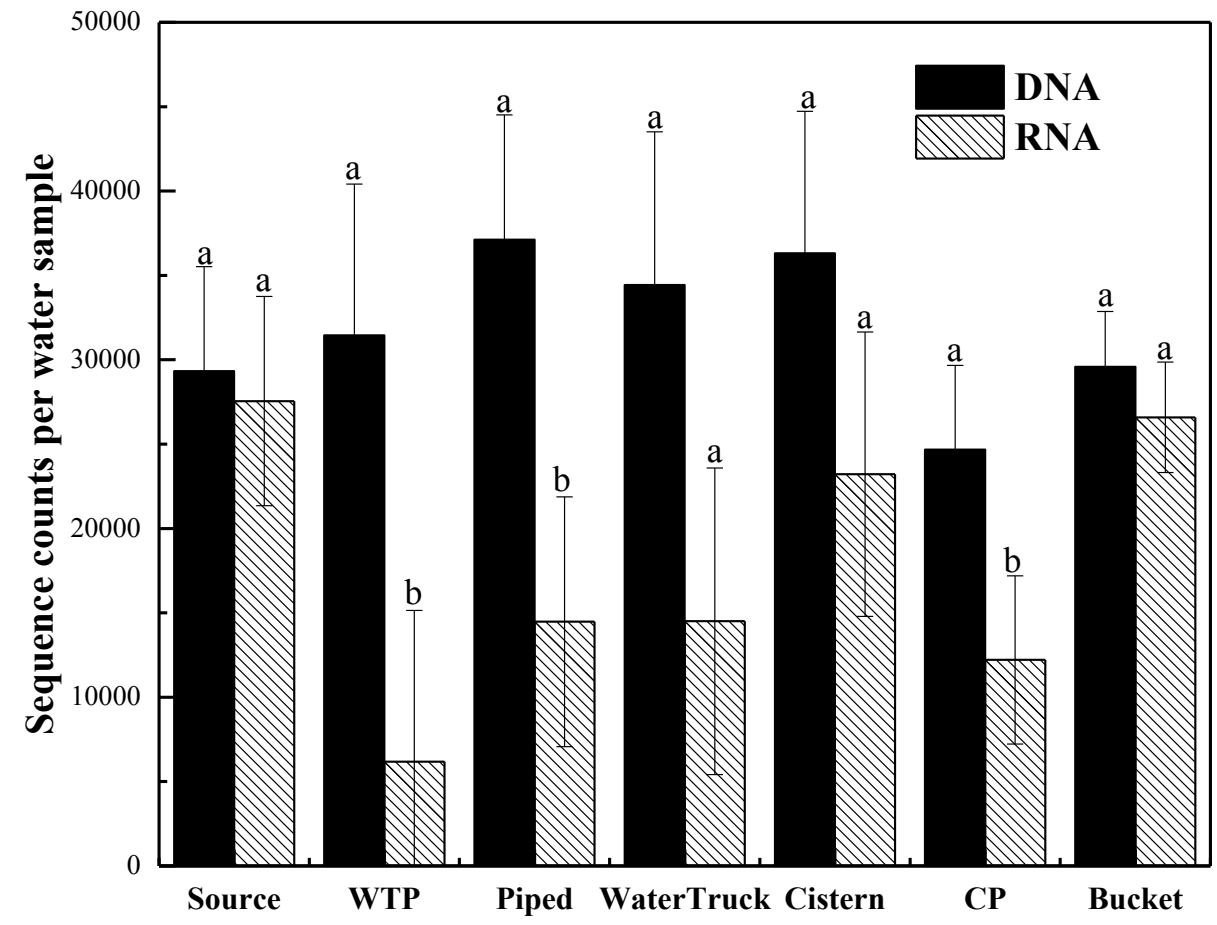


Figure 3: Phyla detected in source (lake) water and the drinking water supplies in the First Nation community examined using (a) DNA- and (b) RNA-based methods. For Proteobacteria $(\mathrm{PB})$, the class is indicated. WTP $=$ water treatment plant. $\mathrm{CP}=$ community standpipe.

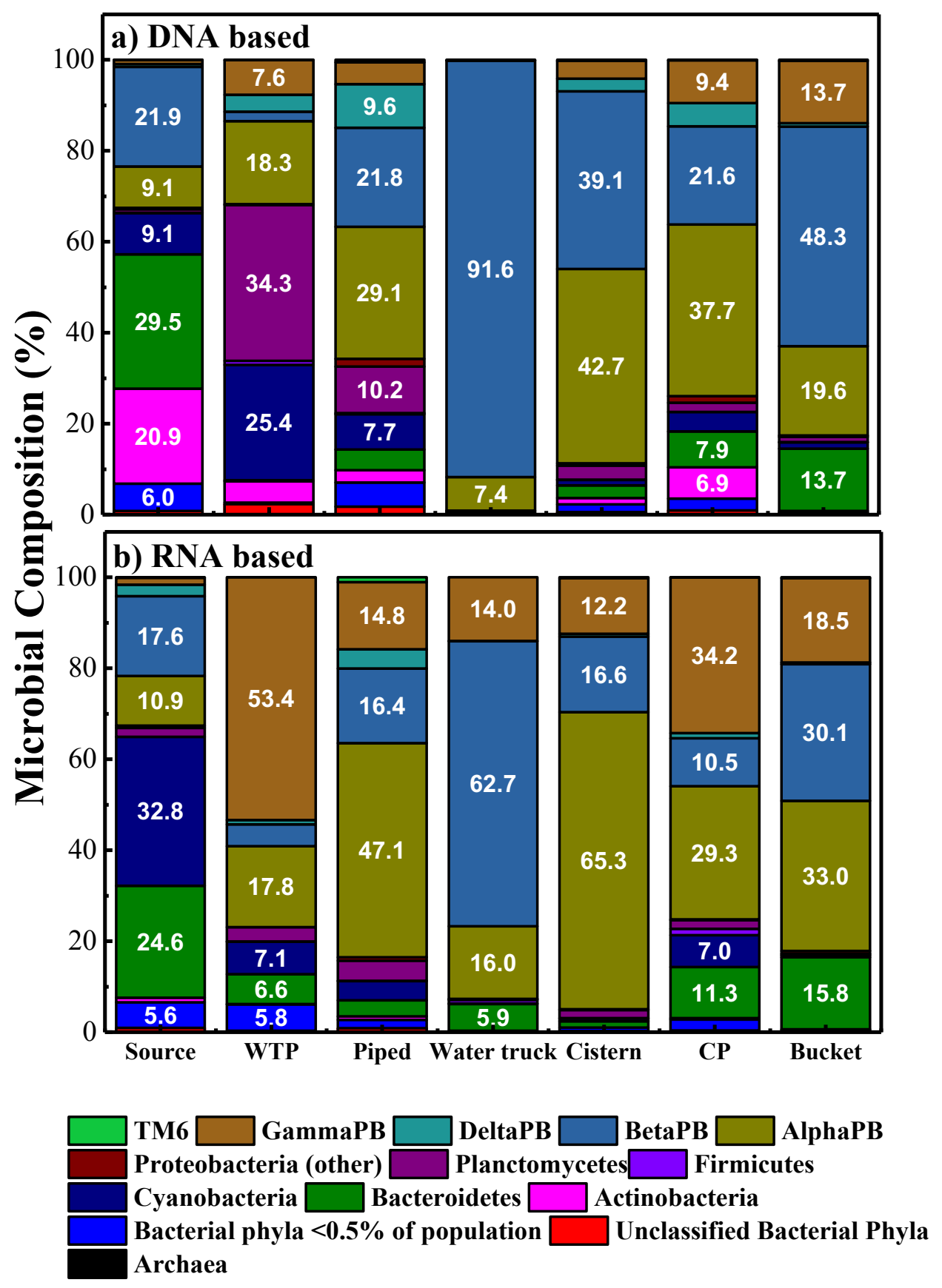


Figure 4: Alpha-diversity in source (lake) water and the drinking water supplies in the First Nation community examined using (a) DNA- and (b) RNA-based methods. WTP = water treatment plant. $\mathrm{CP}=$ community standpipe.

\section{a) DNA based}

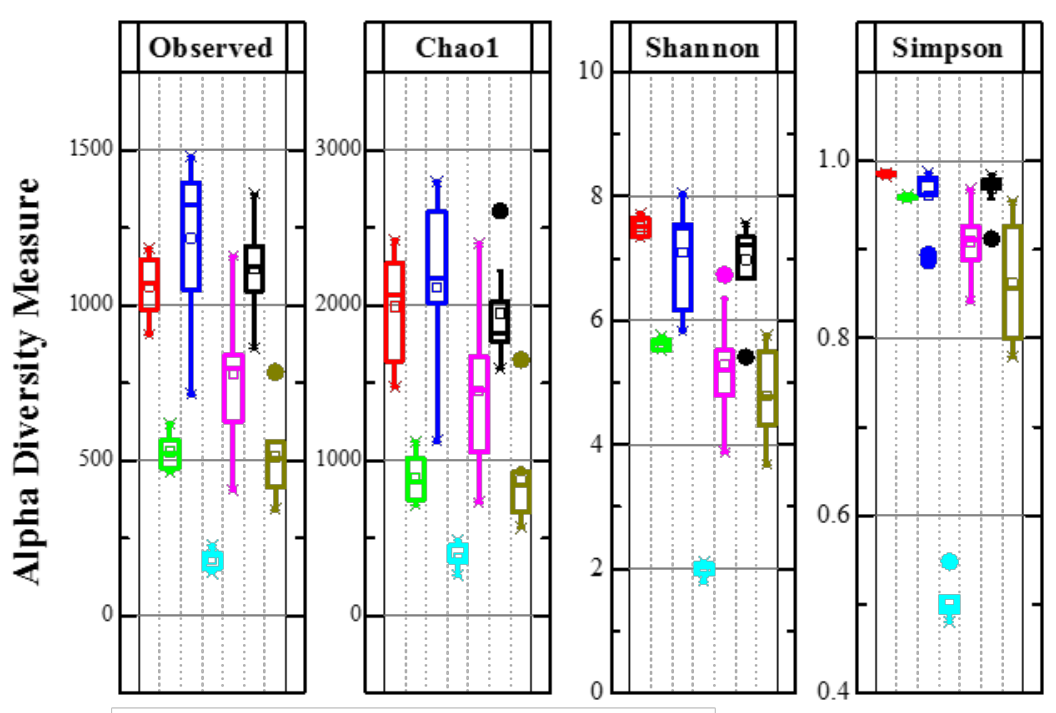

b) RNA based

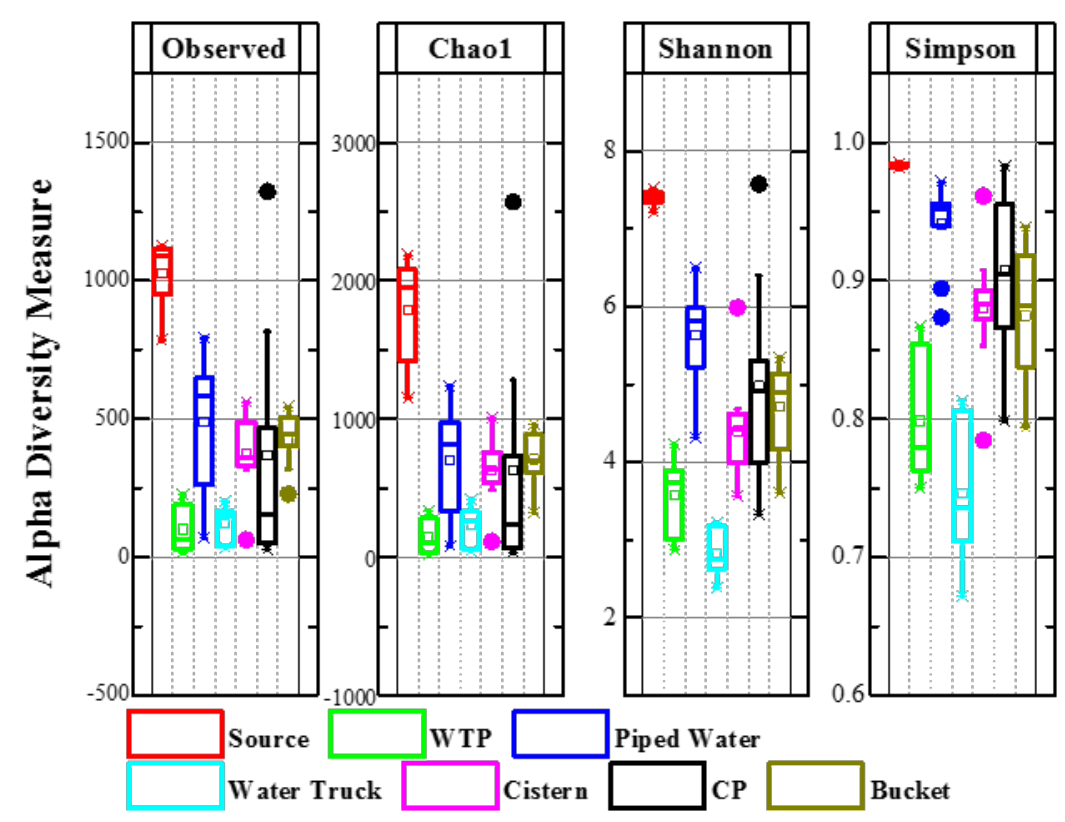


Table 1. Orders of viable Proteobacteria bacteria detected in source (lake) water and the drinking water supplies in the First Nation community examined, expressed as a \% of total sequence counts of Proteobacteria detected. Numbers in brackets refer to mean sequences counts followed by $\%$ coefficient of variation among samples. Letters in brackets, A, B and G, refer to Alpha-, Beta- and Gammaproteobacteria, respectively. WTP $=$ water treatment plants, $\mathrm{CP}=$ community standpipe.

\begin{tabular}{|c|c|c|c|c|c|c|c|}
\hline Order (Class) & $\begin{array}{l}\text { Source } \\
(n=10)\end{array}$ & $\begin{array}{l}\text { WTP } \\
(n=6)\end{array}$ & $\begin{array}{c}\text { Piped } \\
(n=10)\end{array}$ & $\begin{array}{c}\text { Truck } \\
(n=6)\end{array}$ & $\begin{array}{c}\text { Cistern } \\
(n=10)\end{array}$ & $\begin{array}{c}C P \\
(n=8)\end{array}$ & $\begin{array}{c}\text { Buckets } \\
(n=10)\end{array}$ \\
\hline Caulobacterales (A) & $\begin{array}{c}\mathbf{5 . 8 \%} \\
(473,50)\end{array}$ & $\begin{array}{c}\mathbf{0 . 3 \%} \\
(12,220)\end{array}$ & $\begin{array}{c}\mathbf{1 . 6 \%} \\
(169,80)\end{array}$ & $\begin{array}{c}\mathbf{0 . 1 \%} \\
(10,230)\end{array}$ & $\begin{array}{c}\mathbf{1 . 1 \%} \\
(237,110)\end{array}$ & $\begin{array}{c}\mathbf{4 . 5 \%} \\
(314,110)\end{array}$ & $\begin{array}{c}\mathbf{1 0 . 0 \%} \\
(2044,140)\end{array}$ \\
\hline Rhizobiales (A) & $\begin{array}{c}7.7 \% \\
(632,20)\end{array}$ & $\begin{array}{c}\mathbf{1 0 . 6 \%} \\
(480,130)\end{array}$ & $\begin{array}{c}\mathbf{2 7 . 0 \%} \\
(2798,70)\end{array}$ & $\begin{array}{c}\mathbf{3 . 2 \%} \\
(457,110)\end{array}$ & $\begin{array}{c}21.3 \% \\
(4510,50)\end{array}$ & $\begin{array}{c}\mathbf{1 8 . 7 \%} \\
(1297,170)\end{array}$ & $\begin{array}{c}\mathbf{1 1 . 8 \%} \\
(2420,110)\end{array}$ \\
\hline Rhodospirillales (A) & $\begin{array}{c}\mathbf{6 . 1 \%} \\
(498,40)\end{array}$ & $\begin{array}{c}1.2 \% \\
(55,140)\end{array}$ & $\begin{array}{c}11.3 \% \\
(1171,80)\end{array}$ & $\begin{array}{c}\mathbf{0 . 1} \% \\
(11,130)\end{array}$ & $\begin{array}{c}\mathbf{2 9 . 2 \%} \\
(6193,70)\end{array}$ & $\begin{array}{c}\mathbf{9 . 7 \%} \\
(675,120)\end{array}$ & $\begin{array}{c}3.1 \% \\
(633,90)\end{array}$ \\
\hline Sphingomonadales (A) & $\begin{array}{c}\mathbf{4 . 8 \%} \\
(393,80)\end{array}$ & $\begin{array}{c}16.5 \% \\
(748,140)\end{array}$ & $\begin{array}{c}16.4 \% \\
(1700,70)\end{array}$ & $\begin{array}{c}\mathbf{1 7 . 1 \%} \\
(2411,90)\end{array}$ & $\begin{array}{c}17.3 \% \\
(3661,50)\end{array}$ & $\begin{array}{c}\mathbf{1 0 . 4 \%} \\
(723,130)\end{array}$ & $\begin{array}{c}9.8 \% \\
(2014,60)\end{array}$ \\
\hline Burkholderiales (B) & $\begin{array}{c}\mathbf{4 9 . 6 \%} \\
(4068,40)\end{array}$ & $\begin{array}{c}1.6 \% \\
(73,40)\end{array}$ & $\begin{array}{c}22.1 \% \\
(2289,70)\end{array}$ & $\begin{array}{c}\mathbf{7 5 . 0 \%} \\
(10586,90)\end{array}$ & $\begin{array}{c}\mathbf{1 8 . 0 \%} \\
(3812,70)\end{array}$ & $\begin{array}{c}\mathbf{1 9 . 8 \%} \\
(1373,110)\end{array}$ & $\begin{array}{c}35.8 \% \\
(7349,60)\end{array}$ \\
\hline Pseudomonadales (G) & $\begin{array}{c}\mathbf{1 . 0 \%} \\
(79,160)\end{array}$ & $\begin{array}{c}10.1 \% \\
(459,50)\end{array}$ & $\begin{array}{c}\mathbf{2 . 1} \% \\
(214,80)\end{array}$ & $\begin{array}{c}\mathbf{1 . 4 \%} \\
(20,120)\end{array}$ & $\begin{array}{c}\mathbf{0 . 9 \%} \\
(182,140)\end{array}$ & $\begin{array}{c}12.9 \% \\
(895,120)\end{array}$ & $\begin{array}{c}\mathbf{1 5 . 4 \%} \\
(3149,150)\end{array}$ \\
\hline Xanthomonadales $(\mathrm{G})$ & $\begin{array}{c}\mathbf{0 . 5 \%} \\
(39,30)\end{array}$ & $\begin{array}{c}\mathbf{5 6 . 5 \%} \\
(2570,140)\end{array}$ & $\begin{array}{c}\mathbf{1 1 . 0 \%} \\
(1140,140)\end{array}$ & $\begin{array}{c}\mathbf{0 . 8 \%} \\
(116,100)\end{array}$ & $\begin{array}{c}\mathbf{8 . 1 \%} \\
(1716,110)\end{array}$ & $\begin{array}{c}\mathbf{1 3 . 2 \%} \\
(913,170)\end{array}$ & $\begin{array}{c}\mathbf{9 . 2 \%} \\
(1884,120)\end{array}$ \\
\hline TOTAL ORDERS & 37 & 18 & 30 & 15 & 31 & 32 & 25 \\
\hline$\%$ Other Orders & $24.6 \%$ & $3.3 \%$ & $8.4 \%$ & $2.3 \%$ & $4.1 \%$ & $10.6 \%$ & $5 \%$ \\
\hline
\end{tabular}

